\title{
Immunitety międzynarodowe w orzecznictwie Europejskiego Trybunału Praw Człowieka
}

\section{Uwagi wstępne}

Celem niniejszego opracowania jest wskazanie najważniejszych problemów poruszonych w orzeczeniach Europejskiego Trybunału Praw Człowieka (dalej: Trybunał, ETPC) na tle immunitetów wynikających ze zwyczajowych lub traktatowych norm prawa międzynarodowego publicznego, a także sformułowanie tez i ocen związanych z kierunkami rozwoju orzecznictwa strasburskiego w tej dziedzinie. W związku z powyższym poza spektrum zainteresowania znalazły się sprawy dotyczące immunitetów regulowanych prawem krajowym, w tym np. immunitetu parlamentarnego. Na marginesie można natomiast wspomnieć, że ETPC miał okazję zajmować się także tego typu immunitetami'.

Problematyka immunitetów regulowanych prawem międzynarodowym, w tym zwłaszcza immunitet państw i organizacji międzynarodowych, wzbudza od wielu lat zainteresowanie doktryny2. W ostatniej dekadzie dyskusji doktrynalnej sprzyja m.in. skodyfikowanie norm dotyczących immunitetu państwa w Konwencji ONZ w sprawie immunitetów jurysdykcyjnych państw i ich mienia

${ }^{1}$ Zob. M. Kloth, Immunities and the right of access to court under Article 6 of the European Convention on Human Rights, Boston-Leiden 2010, s. 186-197. Zob. także M. Balcerzak, O immunitecie parlamentarnym i granicach wolności wypowiedzi - uwagi na tle wyroku Europejskiego Trybunału Praw Człowieka w sprawie A. v. Zjednoczonemu Królestwu z 17.12.2002 r., KPP 2003, nr 2, s. 209-223.

${ }^{2}$ Zob. m.in. H. Fox, The law of state immunity, wyd. 2, Oxford 2008, wraz z zawartą tam literaturą przedmiotu, a także J. Finke, Sovereign immunity: rule, comity or something else?, EJIL 2010, vol. 21, no. 4, s. 853-881. 
z 2.12.2004 r. ${ }^{3}$, a także rozstrzygnięcia sądów międzynarodowych dotyczące tej problematyki, z wiodącym wyrokiem Międzynarodowego Trybunału Sprawiedliwości w sprawie immunitetów jurysdykcyjnych państwa (RFN v. Włochom) ${ }^{4}$. Jednym z najbardziej ożywionych nurtów tej debaty są studia i glosy poświęcone rozstrzygnięciom ETPC z początku XXI w., jak i z okresu późniejszego - chodzi tu o trzy orzeczenia tego Trybunału z 21.11.2001 r., z których niewątpliwie najwięcej krytyki (ale także głosów aprobatywnych) wywołał wyrok w sprawie Al-Adsani v. Zjednoczonemu Królestwu ${ }^{5}$. Dyskusja na temat zasadności obowiązywania immunitetu państwa dla ochrony przed roszczeniami ofiar tortur wydaje się wciąż aktualna, mimo potwierdzenia tez z wyroku Al-Adsani w wyroku Jones i inni v. Zjednoczonemu Królestwu ${ }^{6}$.

Wśród powodów, dla których tematyka immunitetów w orzecznictwie ETPC zasługuje na uwagę, należy wymienić nie tylko frapujące kwestie związane z potencjalnym ograniczaniem prawa dostępu do sądu przez zastosowanie immunitetów, lecz także ewentualny wpływ rozstrzygnięć ETPC na rozwój prawa międzynarodowego regulującego kwestie immunitetu państwa. W mniejszym stopniu dotyczy to innych rodzajów immunitetów regulowanych prawem międzynarodowym z uwagi na fakt, że polem największej aktywności judykacyjnej ETPC zdaje się być obszar law of state immunity?

${ }^{3}$ The United Nations Convention on Jurisdictional Immunities of States and their property, rezolucja Zgromadzenia Ogólnego ONZ nr 59/38, tekst dostępny na stronie http://treaties.un.org.

${ }^{4}$ Jurisdictional Immunities of the State (Germany v. Italy), wyrok MTS z 3.2.2012 r. Zob. na ten temat M. Kałduński, The Law of State Immunity in the Case concerning "Jurisdictional Immunities of the State (Germany v. Italy)”, „The Law and Practice of International Courts and Tribunals" 2014, vol. 13, issue 1, s. 54-102 oraz R. van Alebeek, Jurisdictional Immunities of the State: (Germany v. Italy): On Rights Outcomes and Wrong Terms, „German Yearbook of International Law" 2012, vol. 55, s. 281-218.

${ }^{5}$ Zob. na temat tego wyroku m.in.: H. Tigroudja, La Cour européenne des droits de l'homme et les immunités juridictionnelles d'États: observations sous les arrêts McElhinney, Fogarty et Al-Adsani contre Royaume-Uni du 21 novembre 2001, RBDI 2001, vol. 34, issue 2, s. 526-548; C. J. Tams, Schwierigkeiten mit dem Ius Cogens, Anmerkungen zum Urteil des Europäischen gerichtshofs für Menschenrechte im Fall Al-Adsani Gegen Vereinigtes Königreich vom 21. November 2001, Archiv des Völkerrecht 2002, vol. 40, issue 3, s. 331-349; X. Yang, State immunity in the European Court of Human Rights: reaffirmations and misconceptions, BJIL 2003, s. 333-408; L. M. Caplan, State immunity, human rights, and jus cogens: a critique of the normative hierarchy theory, AJIL 2003, vol. 97, no. 4, s. 741-781; E. Voyiakis, Access to court v. state immunity, ICLQ 2003, vol. 52, s. 297-332; H. Fox, State immunity and the international crime of torture, EHRLR 2006, issue 2, s. 142-157; K. Parlett, Immunity in civil proceedings for torture: the emerging exception, EHRLR 2006, issue 1, s. 49-66; L. McGregor, Torture and state immunity: deflecting impunity, distorting sovereignty, EJIL 2007, vol. 18, no. 5, s. 903-919; E. Bates, State immunity for torture, HRLR 2007 , vol. 7, no. 4, s. 651-680; A. Orakhelashvili, State immunity and international public order revisited, GJIL 2006, vol. 49, s. 327-365.

${ }^{6}$ Wyrok ETPC z 14.1.2014 r. (skargi nr 34356/06 i 40528/06).

7 Zob. M. Forowicz, The Reception of International Law in the European Court of Human Rights, Oxford 2010, s. 283-313. 
Tytułem wstępu warto przypomnieć, że wprawdzie jurysdykcja ETPC obejmuje sprawy dotyczące interpretacji i stosowania Europejskiej konwencji o ochronie praw człowieka i podstawowych wolności z 4.11.1950 r. (dalej: Konwencja, EKPC) wraz z jej protokołami (por. art. 32 ust. 1 EKPC), to jednak - przynajmniej z formalnego punktu widzenia - sędziowie ETPC są także sędziami Europejskiego Trybunału ds. Immunitetu Państwa (European Tribunal on matters of State Immunity). Jest to ,zapomniana” instytucja, ukonstytuowana na mocy Protokołu dodatkowego do Europejskiej konwencji o immunitecie państwa z 16.5.1972 r. (Konwencja bazylejska) ${ }^{8}$. Trybunał ds. Immunitetu nie miał nigdy okazji orzekać, co należy łączyć m.in. z niewielką liczbą państw-stron Konwencji bazylejskiej (8), jak i Protokołu dodatkowego (6). Inicjatywa powołania takiego organu mogła wynikać z przewidywań państw członkowskich Rady Europy co do pojawienia się sporów na tle tej Konwencji, jednak rzeczywistość podważyła potrzebę funkcjonowania wyspecjalizowanego trybunału zajmującego się immunitetem państwa.

EKPC nie zawiera postanowień odnoszących się wprost do immunitetów regulowanych prawem międzynarodowym - wyjątkiem jest tu art. 51 Konwencji, ale dotyczy on immunitetu sędziów ETPC i nie ma nic wspólnego z zakresem zobowiązań państw-stron wobec podmiotów chronionych. Gros spraw rozstrzyganych przez ETPC w kontekście immunitetów ma związek z kwestią dopuszczalności ograniczenia prawa do sądu, stanowiącego element prawa do rzetelnego procesu (art. 6 ust. 1 EKPC) wskutek działania immunitetu.

W orzecznictwie ETPC można wyróżnić co najmniej kilka wiodących problemów związanych z funkcjonowaniem immunitetu jurysdykcyjnego. Należą do nich:

a) problem dopuszczalności formalnej powództw wnoszonych przez pracowników misji dyplomatycznych przed sądami państwa przyjmującego;

b) problem odpowiedzialności państwa-strony EKPC w przypadku skutecznego powołania się przez państwo pozwane na immunitet jurysdykcyjny przed sądem państwa obcego, w sytuacji, gdy stawiane zarzuty dotyczą zakazu tortur (art. 3 EKPC) lub innych naruszeń praw człowieka o szczególnie poważnym charakterze (serious violations of human rights);

c) problem skuteczności powoływania się przez państwo pozwane na immunitet jurysdykcyjny w związku z wyrządzeniem szkody na osobie wskutek działania sił zbrojnych (personal injury exception).

Niniejsze opracowanie ma na celu analizę wskazanych wyżej problemów. Warto jednak wskazać, że w orzecznictwie ETPC obecne są także przykłady rozstrzygnięć dotyczących innych rodzajów immunitetu, tj. immunitetu egzekucyjnego państwa ${ }^{9}$ oraz immunitetu organizacji międzynarodowych ${ }^{10}$.

${ }^{8}$ European Treaty Series No. 074A, art. 3.

${ }^{9}$ Zob. decyzje ETPC z 12.12.2002 r. w sprawie Kaloageropoulou i inni v. Grecji i RFN, z 4.3.2005 r. w sprawie Manoilescu i Dobrescu v. Rumunii i Rosji oraz z 27 lipca 2007 r. w sprawie Hirschhorn v. Rumunii. Zob. także M. Kloth, op. cit., s. 88-105.

${ }_{10}$ Zob. wyrok ETPC w sprawie Waite and Kennedy v. RFN oraz Beer and Regan v. RFN z 18 lutego 1999 r. 
W odniesieniu do ostatniego z immunitetów, stanowisko dopuszczające ograniczenie prawa dostępu do sądu w związku z działaniem immunitetu jurysdykcyjnego organizacji międzynarodowej - wyrażone przez Trybunał w sprawach przeciwko RFN z 1999 r. - wydaje się aktualne i nie było przedmiotem kontestacji w doktrynie, aczkolwiek zasadne są głosy przypominające o konieczności zapewnienia skarżącym (powodom) adekwatnych i efektywnych metod alternatywnego rozpatrzenia sporu z organizacją międzynarodową ${ }^{11}$.

\section{Kilka uwag o immunitecie głowy państwa i wysokich funkcjonariuszy państwowych w orzeczeniach ETPC}

Przed omówieniem problematyki immunitetu jurysdykcyjnego państwa, warto poczynić kilka uwag odnośnie do orzecznictwa ETPC dotyczącego immunitetu głowy państwa oraz - w szerszym kontekście - immunitetu wysokich funkcjonariuszy państwowych. Co do zasady są to kwestie, które mogłyby zostać omówione łącznie, jednak dla czytelności wywodu należy najpierw poruszyć temat immunitetu głowy państwa. Kwestia ta wystąpiła między innymi na kanwie sprawy Association SOS Attentats and Béatrix de Boëry v. Francji ${ }^{12}$, dotyczącej powództwa przeciwko pułkownikowi Muammarowi al-Kaddafiemu w związku z zamachem terrorystycznym na samolot linii PanAm w 1992 r. ETPC nie rozpoznał tej sprawy co do meritum z uwagi na ugodę, do jakiej doszło pomiędzy rodzinami ofiar a Gaddafi International Foundation for Charity Association. Stanowisko co do obowiązywania immunitetu głowy państwa w tej sprawie wyraził jedynie rząd brytyjski interweniujący jako strona trzecia. W opinii interwenienta, powołującego się m.in. na wyrok MTS w sprawie Kongo v. Belgii ${ }^{13}$, przywódca Libii objęty był immunitetem jurysdykcyjnym wobec powództw cywilnoprawnych i zarzuty w kontekście art. 6 ust. 1 EKPC nie miały umocowania w związku z brakiem zastosowania tego postanowienia do przedmiotowej sprawy ${ }^{14}$.

${ }^{11}$ Zob. A. Reinisch, U. A. Weber, In the shadow of Waite and Kennedy: the jurisdictional immunity of international organizations, the individual's right of access to the courts and administrative tribunals as alternative means of dispute settlement, IOLR 2004, vol. 1, s. 59-110. Zob. także artykuł Prof. J. Menkesa nt. immunitetu organizacji międzynarodowych w niniejszym zbiorze.

${ }_{12}$ Zob. decyzję Wielkiej Izby z 4.10.2006 r. Zob. także M. Kloth, op. cit., s. 110-114.

13 Arrest Warrant of 11 April 2000 (Democratic Republic of the Congo v. Belgium), wyrok MTS z 14.2.2002 r.

${ }^{14}$ Por. pkt 26 i 27 wyroku ETPC w sprawie Association SOS Attentats and Béatrix de Boëry. 
Problematyka immunitetu głowy państwa wobec jurysdykcji karnej pojawiła się w tle skargi Saddama Husseina przeciwko 21 państwom-stronom EKPC ${ }^{15}$, jednak Trybunał jednogłośnie uznał ją za niedopuszczalną z uwagi na brak jurysdykcji państw-stron w rozumieniu art. 1 EKPC. Można jedynie domniemywać, że gdyby doszło do rozpatrywania sprawy co do meritum, kwestia immunitetu Husseina jako byłego prezydenta Iraku mogłaby mieć pewne znaczenie, podobnie jak zagadnienie dopuszczalności przekazania b. prezydenta Iraku do osądzenia w jurysdykcji, w której stosuje się karę śmierci. Jak wiadomo, decyzje państw koalicji antyreżimowej w tamtym czasie oraz orzeczenie sądu irackiego w sprawie Husseina czynią rozważania na ten temat bezprzedmiotowymi.

Pośredniego związku z problematyką immunitetu głowy państwa można dopatrywać się w wyroku ETPC w sprawie Streletz, Kessler i Krenz przeciwko $R F N^{16}$, dotyczącej zarzutów naruszenia zasady lex retro non agit wobec osób ukaranych po zjednoczeniu Niemiec z tytułu odpowiedzialności za rozkaz strzelania do osób podejmujących ucieczkę z NRD przez mur berliński ${ }^{17}$. Jeden ze skarżących w tej sprawie - Egon Krenz - był przez kilka miesięcy przewodniczącym Rady Państwa NRD, co może rodzić pytania o zakres przysługującego mu z tego tytułu immunitetu. Jednakże problem ten nie został poruszony przez strony postępowania przed ETPC, a zakres kognicji Trybunału ograniczał się do rozpoznania zarzutów na tle art. 7 EKPC.

Jeśli chodzi o immunitet funkcjonariuszy państwowych przed jurysdykcją sądów państw obcych, to należy odnotować wspomniany już i wiodący w tym zakresie wyrok ETPC w sprawie Jones $i$ inni v. Zjednoczonemu Królestwu. O ile w odniesieniu do problematyki immunitetu państwa wyrok ten został w całości oparty na tezach rozstrzygnięcia Al-Adsani z 2001 r. oraz wyroku MTS w sprawie $R F N v$. Włochom, o tyle rozstrzygając zarzuty naruszenia prawa do sądu w związ$\mathrm{ku} \mathrm{z}$ oddaleniem przez sądy brytyjskie powództwa cywilnoprawnego przeciwko ministrowi spraw wewnętrznych Arabii Saudyjskiej i innym funkcjonariuszom państwowym, Izba Trybunału dokonała „samodzielnej” oceny istniejących norm prawa międzynarodowego publicznego i sądowej praktyki państw w tej dziedzinie.

Dla ustalenia istniejących norm dotyczących immunitetu funkcjonariuszy państwowych w prawie międzynarodowym Trybunał powołał się między innymi na prace Komisji Prawa Międzynarodowego ONZ, a konkretnie na drugi raport specjalnego sprawozdawcy Romana A. Kolodkina ${ }^{18}$, podkreślając powszechne

\footnotetext{
15 Skarga nr 23276/04. Decyzja ETPC o niedopuszczalności z 14.3.2006 r.

16 Wyrok ETPC z 22.3.2001 r.

${ }^{17}$ Por. na ten temat J. Zajadło, Odpowiedzialność za mur. Procesy strzelców przy murze berlińskim, Gdańsk 2003, 2007, passim.

${ }^{18}$ R. A. Kolodkin, Second report on immunity of State officials from foreign criminal jurisdiction, 10 June 2010, sygn. A/CN.4/631. Kolejne raporty na ten temat (w latach 2011-2014) były przedstawiane na forum Komisji Prawa Międzynarodowego przez nową sprawozdawczynię: C. E. Hernández.
} 
uznanie istnienia immunitetu funkcjonariuszy jako normy ogólnej, od której dopuszczalne są wyjątki na zasadzie norm szczególnych lub normy prawa zwyczajowego ${ }^{19}$. Trybunał odnotował, że jednostki korzystają z immunitetu ratione materiae tylko wówczas, gdy zaskarżone działania zostały podjęte w ramach ich obowiązków urzędowych, co potwierdza między innymi brzmienie art. 2 ust. 1 (b) iv Konwencji ONZ w sprawie immunitetów jurysdykcyjnych państw i ich mienia $^{20}$. Ustalony w wyroku Al-Adsani i potwierdzony w wyroku Jones brak normy wyłączającej immunitet państwa w przypadku naruszenia norm o charakterze ius cogens (tzw. ius cogens exception) nie przesądza - zdaniem Trybunału - o braku jakichkolwiek wyjątków od normy dotyczącej immunitetu funkcjonariuszy państwowych $^{21}$. Dla rozstrzygnięcia tej kwestii Trybunał wykorzystał szereg źródeł: po pierwsze, odwołał się do definicji tortur z Konwencji ONZ przeciwko torturom z 1984 r. $^{22}$, która uznaje tortury za akty ,,popełnione przez urzędnika publicznego lub inną osobę działającą w tym charakterze”. Kwestia „urzędowego charakteru" tortur i wpływu takiej definicji na zagadnienie wyjątku od immunitetu funkcjonariusza/urzędnika państwowego była już przedmiotem rozważań w orzeczeniach krajowych, w tym przez brytyjską Izbą Lordów w sprawie Jones i Mitchell. Wprawdzie brytyjski sąd apelacyjny rozstrzygający tę sprawę zakwestionował wymóg „urzędowego" działania sprawcy tortur dla wypełnienia ich definicji, jednakże Izba Lordów jednogłośnie uznała, że ten punkt widzenia wywodzi się przede wszystkim z wyroków sądów amerykańskich i nie stanowi głównego nurtu w innych jurysdykcjach. W świetle obowiązującego prawa międzynarodowego tortury są zatem aktem ,urzędowym”. Ponadto trudno z przekonaniem stwierdzić - mimo progresywnej interpretacji Komitetu Przeciwko Torturom - że Konwencja ONZ z 1984 r. uchyliła normy dotyczące immunitetu funkcjonariuszy państwa i de facto wprowadziła zasadę uniwersalnej jurysdykcji cywilnoprawnej ${ }^{23}$.

Po drugie, Trybunał przypomniał normy dotyczące przypisania aktu państwu, sformułowane w Artykułach Komisji Prawa Międzynarodowego o odpowiedzialności państwa za akt międzynarodowo bezprawny ${ }^{24}$, które nie stają na przeszkodzie, aby niezależnie od odpowiedzialności państwa egzekwować

19 Por. pkt 202 wyroku ETPC w sprawie Jones.

${ }^{20}$ W brzmieniu: Dla celów niniejszej Konwencji (...) ,Państwo” oznacza (...) przedstawicieli tego państwa działających $w$ tym charakterze (tłum. autora).

${ }^{21}$ Por. pkt 205 wyroku ETPC w sprawie Jones.

${ }^{22}$ Konwencja ONZ w sprawie zakazu stosowania tortur oraz innego okrutnego, nieludzkiego lub poniżającego traktowania albo karania, przyjęta rezolucją Zgromadzenia Ogólnego ONZ nr 39/46 z dnia 10.12.1984 r.

${ }^{23}$ Zob. pkt 208 wyroku ETPC w sprawie Jones oraz art. 14 Konwencji ONZ z 1984 r. (obowiązek zapewnienia ofierze tortur zadośćuczynienia i prawa do odszkodowania w systemie prawnym państwa-strony).

${ }^{24}$ Zob. Zob. Articles on Responsibility of States for Internationally Wrongful Acts, przyjęte na 53. sesji KPM i przedłożone Zgromadzeniu Ogólnemu ONZ (załącznik do rezolucji nr 53/83 z 12.12.2001 r.). 
odpowiedzialność indywidualną sprawcy aktu, zwłaszcza w przypadku tortur. Zatem nawet jeżeli dla celów prawa o odpowiedzialności (a konkretnie przypisania) ustalony zostanie „urzędowy” charakter aktu państwa, nie stanowi to samo w sobie argumentu rozstrzygającego kwestię przyznania temu państwu immunitetu ${ }^{25}$.

Po trzecie, Trybunał odnotował, że prawo o odpowiedzialności państwa nie poświęca zbyt wiele uwagi dopuszczalności uchylenia immunitetu funkcjonariuszy państwowych w przypadku popełnienia tortur: żadnych wskazówek na ten temat nie zawiera ani Konwencja bazylejska, ani Konwencja ONZ z 2004 r. Można jedynie stwierdzić, że trwa na ten temat wymiana poglądów, a osiągnięcie konsensu jest wciąż dalekie. Nie ma także wystarczających dowodów krajowej praktyki sądowej: powództwa cywilnoprawne przeciwko funkcjonariuszom państw obcych w związku ze stosowaniem tortur są nieliczne, a wśród zapadłych orzeczeń krajowych dominują stanowiska powściągliwe wobec uchylania immunitetu w takich przypadkach. Także w sądach amerykańskich, które mają więcej okazji do rozpatrywania takich powództw ${ }^{26}$, brak jednoznacznej linii orzeczniczej.

W świetle powyższego Trybunał uznał, że „mimo pojawiającego się wsparcia na rzecz szczególnej reguły lub wyjątku w prawie międzynarodowym publicznym w sprawach dotyczących cywilnoprawnych powództw z tytułu tortur przeciwko funkcjonariuszom państw obcych, większość argumentów (...) świadczy o tym, że prawo państwa do immunitetu nie może być obchodzone poprzez pozywanie w zastępstwie ich urzędników lub funkcjonariuszy. (...) Praktyka państw w tym zakresie jest płynna, obejmując zarówno przypadki uznania, jak i odmowy uznania immunitetu ratione materiae (...)"27.

W konkluzji Trybunał nie stwierdził naruszenia art. 6 Konwencji w związku z przyznaniem przez sądy brytyjskie immunitetu funkcjonariuszom państwa obcego, pozwanym przez skarżących w sprawie Jones $i$ inni. Wyrok kończy się jednak znamiennym sformułowaniem: „w świetle zachodzących obecnie zmian $\mathrm{w}$ tej dziedzinie prawa międzynarodowego ( $\mathrm{tj}$. prawa o immunitetach - przyp. M. B.), jest to kwestia, która musi być poddawana przeglądowi (ang. be kept under review) przez Układające się Strony"28.

Wyrok ETPC w sprawie Jones należy uznać za odzwierciedlający aktualny stan prawa międzynarodowego publicznego w dziedzinie immunitetu funkcjonariuszy państwowych. Na aprobatę zasługuje szerokie spektrum analizy dokonanej przez Trybunał dla stwierdzenia, czy „wyjątek ius cogens” został wystarczająco ugruntowany w praktyce krajowej oraz instrumentach międzynarodowych. Negatywny wynik tej analizy nie pozostawiał wątpliwości co do rozstrzygnięcia zarzutów naruszenia art. 6 ust. 1 Konwencji. Podobnie jak w przypadku orzekania

${ }^{25}$ Por. pkt 207 wyroku ETPC w sprawie Jones.

${ }^{26}$ Zob. obszerny przegląd praktyki sądów amerykańskich w pkt 116-125 wyroku ETPC w sprawie Jones.

27 Zob. pkt 213 wyroku ETPC w sprawie Jones.

${ }^{28}$ Ibidem. 
o immunitecie państwa, także w przypadku immunitetu funkcjonariuszy państwowych ETPC zachował się powściągliwie, nie decydując się na przekroczenie granicy prawotwórstwa sądowego. Z perspektywy humanitarnego wymiaru EKPC i efektywności ścigania sprawców tortur wyrok w sprawie Jones może być rozczarowujący, jednak nie należy tracić z pola widzenia dyskusji na temat „wyjątku ius cogens", która być może doprowadzi do ewolucji stanowiska sądów krajowych w tej materii. Dopiero wówczas będzie można oczekiwać rewizji stanowiska ETPC ze spraw Al-Adsani i Jones.

Na kanwie wywodu Trybunału dotyczącego immunitetu funkcjonariuszy państwowych (w sprawie Jones) warto poczynić jeszcze jedną uwagę: otóż bardzo znamienne jest wielokrotne powoływanie się przez Trybunał na trwające prace Komisji Prawa Międzynarodowego dotyczące immunitetu urzędników państwowych w zakresie jurysdykcji karnej. Jakkolwiek samo odnotowanie tych prac jest całkowicie zrozumiałe, o tyle można się zastanawiać, na ile autorytatywnie można traktować pojedyncze raporty specjalnych sprawozdawców, które nie są przecież stanowiskami całej Komisji, a raczej odzwierciedlają prywatne poglądy doktrynalne. Trybunał z dużą atencją odnosił się do drugiego raportu R. A. Kolodkina; odnotował także raporty C. E. Hernandez. Końcowy wynik prac KPM nad tym zagadnieniem - który może, ale nie musi być zbieżny z poglądami R. A. Kolodkina lub C. E. Hernandez - będzie niewątpliwie istotny dla dalszego rozwoju prawa o immunitecie państwa. Trudno byłoby jednak spodziewać się, że Komisja Prawa Międzynarodowego dokona przełomu i jednoznacznie stwierdzi istnienie „wyjątku ius cogens", zwłaszcza wobec braku ugruntowanej praktyki sądów krajowych i międzynarodowych. Z punktu widzenia rozwoju prawa o immunitecie w kierunku uznania „wyjątku ius cogens” wyrok ETPC nie zawiera żadnych wyraźnych akcentów, które mogłyby być wykorzystane w pracach KPM przez zwolenników ustalenia takiego wyjątku jako normy prawa międzynarodowego.

\section{Powództwa wnoszone przez pracowników misji dyplomatycznej do sądów państwa przyjmującego}

Stanowisko ETPC w kwestii realizacji prawa do rzetelnego procesu przez pracowników misji dyplomatycznej zostało wyrażone w dwóch wiodących precedensach: Fogarty v. Zjednoczonemu Królestwu z 21.11.2001 r. oraz Cudak v. Litwie z 23.3.2010 r. Obie sprawy dotyczyły nieudanej próby pozwania przez byłe pracownice misji dyplomatycznych swojego pracodawcy (tj. państwa wysyłającego w sądach państwa przyjmującego), przy czym w sprawie Fogarty sedno sporu polegało na odmowie zatrudnienia skarżącej, natomiast w sprawie 
Cudak - roszczeniach związanych ze zwolnieniem skarżącej z pracy. W pierwszej sprawie ETPC nie stwierdził naruszenia Konwencji, natomiast w drugiej - uznał, że doszło do naruszenia art. 6 ust 1 EKPC.

Należy przypomnieć, że wprawdzie prawo dostępu do sądu jako element prawa do rzetelnego procesu nie ma charakteru absolutnego, jednak ETPC bardzo wnikliwie przygląda się zarzutom związanym z uniemożliwieniem skierowania sporu przez skarżącego na drogę sądową. Wywiedzenie prawa dostępu do sądu nastąpiło na wczesnym etapie rozwoju orzecznictwa strasburskiego - w wyroku Golder v. Zjednoczonemu Królestwu ${ }^{29}$. U podstaw rozumowania organów kontrolnych Konwencji znajdowało się słuszne skądinąd przekonanie, że dostęp do sądu warunkuje korzystanie z pozostałych elementów prawa do rzetelnego procesu, zatem bez efektywnego dostępu do drogi sądowej prawo zagwarantowane w art. 6 ust. 1 EKPC staje się iluzoryczne. Konwencja nie wprowadza domniemania drogi sądowej ani powszechnego prawa do sądu w każdej sprawie - zakres przedmiotowy tej gwarancji ograniczony jest do tzw. płaszczyzny cywilnej i karnej ${ }^{30}$. Pierwsza z nich dotyczy „,praw i obowiązków o charakterze cywilnym” - twórcy Konwencji użyli tu niezbyt fortunnego sformułowania, którego interpretacja nie należy do najłatwiejszych. Nie ulega jednak wątpliwości, że Trybunał stosuje rozszerzającą wykładnię civil rights and obligations, która powoduje, że spory pracownicze zasadniczo wchodzą w zakres tego pojęcia, z pewnymi wyjątkami.

Jeden $\mathrm{z}$ wyjątków uznanych przez Trybunał za uzasadniający ograniczenie prawa gwarantowanego art. 6 ust. 1 EKPC dotyczył powództw wnoszonych przez urzędników publicznych w odniesieniu do rekrutacji, przebiegu kariery zawodowej i zwolnienia ze służby. Linia orzecznicza ETPC w tej materii została najpierw zmodyfikowana wyrokiem Pellegrin v. Francji (brak zastosowania art. 6 ust. 1 do sporów pracowniczych $\mathrm{w}$ administracji publicznej), a następnie w zasadzie zastąpiona wyrokiem Vilho Eskelinen v. Finlandii ${ }^{31}$, zgodnie z którym należy domniemywać zastosowalność art. 6 do tego typu sporów ${ }^{32}$. Trybunał nie sformułował natomiast żadnej odrębnej koncepcji obowiązywania prawa do rzetelnego procesu w sporach pracowników misji dyplomatycznych z byłym lub obecnym pracodawcą. Jest to zrozumiałe, bowiem w tego typu sytuacjach konieczne jest uwzględnienie obowiązujących reguł prawa międzynarodowego w dziedzinie immunitetu jurysdykcyjnego.

Warto przypomnieć, że w orzecznictwie ETPC nigdy nie zakwestionowało potrzeby funkcjonowania immunitetów jako takich oraz konieczności uwzględniania przez Trybunał norm prawa międzynarodowego w tym zakresie.

${ }^{29}$ Wyrok z 21.2.1975 r.

${ }_{30}$ Por. P. Hofmański, A. Wróbel, Artykut 6. Prawo do rzetelnego procesu, [w:] L. Garlicki (red.), Konwencja o ochronie praw człowieka i podstawowych wolności. Komentarz do artykułów 1-18, Warszawa 2010, s. 250 i nast.

${ }^{31}$ Wyroki - odpowiednio - z 8.12.1999 r. i 19.4.2007 r.

32 Zob. P. Hofmański, A. Wróbel, op. cit., s. 269. 
W związku z tym odosobnione jest stanowisko sędziego L. Loucaidesa, wyrażone w opinii odrębnej do wyroku McElhinney v. Irlandii (a także w innych wyrokach), zdaniem którego: „(...) Europejska konwencja praw człowieka stanowi lex specialis. Ogólne zasady prawa międzynarodowego nie są zawarte w Konwencji, z wyjątkiem odniesień wyraźnych, np. w art. 15, art. 35 ust. 1 oraz art. 53 EKPC oraz art. 1 Protokołu nr 1. Dlatego należy niechętnie podchodzić do ograniczeń praw konwencyjnych wywodzonych z zasad prawa międzynarodowego, takich jak zasady dotyczące immunitetów, które nie są nawet częścią norm o charakterze ius cogens (tlum. autora)".

Powyższe stanowisko ilustruje niebezpieczną tendencję polegającą na próbie zdystansowania Konwencji od powszechnego prawa międzynarodowego. Tymczasem nie ma podstaw ani powodów, aby postrzegać normy ETPC jako obowiązujące autonomicznie i bez należytego uwzględnienia innych norm systemu prawa międzynarodowego. W sferze ocen prawnopolitycznych tego typu stanowiska obrazują aktywizm sędziowski oraz zjawisko określone niegdyś przez A. Pellet jako human rightism (we francuskiej wersji: droit-de-l'hommisme) ${ }^{33}$.

Wypowiadając się na temat dopuszczalności ograniczeń prawa do sądu w przypadku powołania się przez państwo pozwane na immunitet jurysdykcyjny, Trybunał dokonuje oceny ingerencji państwa w sferę prawa do rzetelnego procesu, posługując się ugruntowanym orzecznictwem. Należy tu wskazać test sformułowany w sprawie Ashingdane v. Zjednoczonemu Królestwu ${ }^{34}$ i konsekwentnie stosowany w późniejszych wyrokach. Trybunał stwierdził wówczas, że ingerencja (czyli limitacja prawa dostępu do sądu) nie może ograniczać jednostce dostępu do sądu w taki sposób (lub do takiego stopnia), że nadwyrężona jest sama istota tego prawa (ang. (...) that the very essence of the right is impaired) ${ }^{35}$. Ponadto ograniczenie nie będzie zgodne $\mathrm{z}$ art. 6 ust. 1 EKPC, gdy nie zmierza do uzasadnionego celu oraz gdy nie ma rozsądnego związku proporcjonalności między użytymi środkami a zamierzonym celem $^{36}$.

W przypadku oceny ingerencji państwa w prawo do sądu polegającej na odmowie rozpoznania przez sąd krajowy powództwa pracownika misji dyplomatycznej w związku z powołaniem się przez państwo pozwane na immunitet jurysdykcyjny, istotne są następujące postulaty:

- ETPC powinien każdorazowo przeprowadzić gruntowne badanie normy prawa międzynarodowego, która obowiązuje w danym przypadku;

- konieczne jest właściwe scharakteryzowanie rzeczywistego charakteru czynności wykonywanych przez pracownika misji dyplomatycznej oraz rozstrzygnięcie, czy należą one do sfery de iure imperii czy też de iure gestionis.

${ }^{33}$ Gilberto Amado Memorial Lecture, 18.7.2000 r. oraz idem, «Human rightism» and international law, IYIL 2000, vol. 10, s. 3-16.

${ }^{34}$ Wyrok z 28.5.1985 r.

${ }^{35}$ Ibidem, pkt 57 wyroku.

${ }^{36}$ Zob. na ten temat M. Kloth, op. cit., s. 13-18. 
W wyżej wymienionych orzeczeniach Fogarty i Cudak można odnotować tendencję do ograniczania zakresu stosowania immunitetu państwa w sprawach związanych ze sporami pracowniczymi. Mimo że Trybunał w orzeczeniu Cudak podkreślił konieczność rozróżnienia rationes decidendi tego wyroku od sprawy Fogarty, to jednak oba te orzeczenia dotyczą oceny ingerencji w prawo dostępu do sądu obecnego lub byłego pracownika misji dyplomatycznej.

Niezależnie od poważnych zastrzeżeń dotyczących metodologii wywodzenia norm zwyczajowego prawa międzynarodowego przez ETPC w wyroku Cudak ${ }^{37}$, stanowisko wyrażone w sprawie litewskiej świadczy o dynamicznej interpretacji przez ETPC norm prawa międzynarodowego dotyczących immunitetu państwa oraz promowania „podejścia pro-victim”. Jednak niewątpliwie zachowuje aktualność teza z wyroku Fogary, że rekrutacja pracowników misji dyplomatycznej należy do imperium państwa i nie można tu wskazać tendencji do osłabienia immunitetu jurysdykcyjnego w przypadku ewentualnych sporów ${ }^{38}$. Wręcz przeciwnie, art. 11 Konwencji ONZ w sprawie immunitetów jurysdykcyjnych państw i ich mienia, który Trybunał zdaje się uznawać za wyraz prawa zwyczajowego, wyraźnie przewiduje możliwość powołania się na immunitet w takich przypadkach. Spory związane z zakończeniem stosunku pracy w misji dyplomatycznej nie zostały wprost ujęte w powyższym postanowieniu, ale nie oznacza to, aby państwa w każdym przypadku podlegały jurysdykcji sądów państwa przyjmującego. Podstawowym i decydującym kryterium pozostaje (a przynajmniej powinien pozostać) zakres czynności wykonywanych przez danego pracownika ${ }^{39}$.

W odniesieniu do dotychczasowych rozstrzygnięć ETPC dotyczących sporów pracowników misji dyplomatycznych na tle immunitetu jurysdykcyjnego państwa można postawić następujące wnioski:

- ETPC jest gotów uznać Konwencję ONZ z 2004 r. za wiodący punkt odniesienia przy rekonstrukcji norm zwyczajowego prawa międzynarodowego

${ }^{37}$ Zob. M. Balcerzak, M. Kałduński, Immunitet jurysdykcyjny państwa - glosa do wyroku ETPCz z 23.03.2010 r. w sprawie Cudak v. Litwa, EPS 2010, nr 11, s. 40-44. Zastrzeżenia te dotyczą dość powierzchownego - zdaniem autorów - przeglądu praktyki państw przy ustalaniu przez ETPCz istnienia norm prawa zwyczajowego. Problem metodologii ustalania prawa zwyczajowego przez Trybunał porusza I. Ziemele w: Customary international law in the case law of the European Court of Human Rights: the method, „Law and Practice of International Courts and Tribunals” 2013, nr 12(2), s. 243-252.

${ }^{38}$ Por. pkt 38 wyroku Fogarty: Questions relating to the recruitment of staff to missions and embassies may by their very nature involve sensitive and confidential issues, related, inter alia, to the diplomatic and organisational policy of a foreign State. The Court is not aware of any trend in international law towards a relaxation of the rule of State immunity as regards issues of recruitment to foreign missions. (...).

${ }^{39}$ Por. art. 11 ust. a) Konwencji ONZ - functions closely related to the exercise of governmental authority. Argumentem autorów glosy krytycznej do wyroku Cudak było zaniechanie przez ETPCz ustalenia faktycznego zakresu obowiązków skarżącej w ambasadzie RP w Wilnie - M. Balcerzak, M. Kałduński, op. cit., s. 42. 
o immunitecie państwa, przy czym analiza wyroku w sprawie Cudak v. Litwie skłania do wyrażenia obawy, że ETPC zbyt łatwo uznaje normy tej konwencji jako odzwierciedlające prawo zwyczajowe;

- w sytuacji, gdy zakres obowiązków pracownika wnoszącego powództwo przeciwko misji dyplomatycznej/państwu wysyłającemu nie ma zdecydowanie charakteru de iure imperii, należy spodziewać się, że wątpliwości w tym względzie przemawiają za niedopuszczalnością ograniczania drogi sądowej, czyli będą skutkowały stwierdzeniem naruszenia art. 6 ust. 1 EKPC.

Powyższe tezy znajdują swoje potwierdzenie w wyrokach Trybunału w sprawach: Sabeh el Leil v. Francji ${ }^{40}$ (oddalenie przez sądy francuskie powództwa księgowego ambasady Kuwejtu przeciwko Kuwejtowi; naruszenie art. 6 ust. 1 EKPC $\mathrm{w}$ związku z brakiem proporcjonalności i uznanie immunitetu państwa, mimo iż tło faktyczne nie dotyczyło aktów de iure imperii) oraz Wallishauser v. Austrii ${ }^{41}$ (oddalenie przez sądy austriackie roszczeń pracownicy ambasady USA przeciwko Stanom Zjednoczonym; naruszenie art. 6 ust. $1 \mathrm{w}$ związku z uznaniem immunitetu państwa pozwanego).

\section{Problem odpowiedzialności państwa-strony EKPC w przypadku skutecznego powołania się przez państwo pozwane przed sądami państwa-strony na immunitet w związku z zarzutami tortur (art. 3 EKPC) lub innych naruszeń praw człowieka o szczególnie poważnym charakterze (serious violations of human rights)}

Kolejny i być może najgłośniejszy z problemów, jakimi zajmował się ETPC w związku z immunitetem jurysdykcyjnym państwa, dotyczy sytuacji, gdy sądy państwa-strony EKPC odmówiły rozpoznania powództwa przeciwko państwu oskarżanemu o stosowanie tortur. Problem ten stanął na wokandzie ETPC we wspomnianej już sprawie Al-Adsani v. Zjednoczonemu Królestwu i został rozstrzygnięty jednym głosem (9 do 8) na korzyść państwa pozwanego (tj. brak naruszenia art. 6 ust. $1 \mathrm{EKPC})^{42}$.

Większość składu ETPC wyraziła wówczas następującą tezę: „,(..) The Court, while noting the growing recognition of the overriding importance of the prohibition of torture, does not accordingly find it established that there is yet

${ }^{40}$ Wyrok Wielkiej Izby ETPC z 29.06.2011 r. (jednogłośnie).

${ }^{41}$ Wyrok ETPC z 17.07.2012 r.

${ }^{42} \mathrm{Na}$ temat stanu faktycznego i oceny tego wyroku zob. M. Balcerzak, Immunitet państw..., s. 127 i nast. 
acceptance in international law of the proposition that States are not entitled to immunity in respect of civil claims for damages for alleged torture committed outside the forum State (...)" (podkreślenie M. B.) ${ }^{43}$.

Większość ocen wyrażonych $\mathrm{w}$ doktrynie odnosi się krytycznie do tego rozstrzygnięcia, zarzucając mu zbytnią powściągliwość. Zarysowany w wyroku Al-Adsani problem wiąże się z podstawowym pytaniem: jak daleko sięgają obowiązki państw-stron EKPC w związku z działaniami naruszającymi standardy konwencyjne, których nie można przypisać bezpośrednio państwu-stronie? Wprawdzie kluczowy problem dotyczy nie tyle art. 3, co art. 6 ust. 1 Konwencji, niemniej, niezależnie od formalnej klasyfikacji prawnej, trzeba zauważyć, że w wymiarze globalnym nie jest to jedynie spór o dopuszczalność ograniczeń prawa do sądu, lecz spór o zakres obowiązków państwa w sferze proceduralnej ochrony przed torturami.

Powyższe zagadnienie było już przedmiotem rozstrzygnięć ETPC - m.in. w sprawie Soering v. Zjednocznemu Królestwu ${ }^{44}$ na tle dopuszczalności ekstradycji do USA i narażenie skarżącego na karę śmierci (problem death row). W tym przypadku ETPC wypracował koncepcję ofiary potencjalnej i zapobiegł dokonaniu ekstradycji. W sensie formalnym wyrok Soering stanowił rozszerzenie zakresu odpowiedzialności z tytułu Konwencji w celu zagwarantowania, że działanie państwa-strony nie doprowadzi do nieuchronnego naruszenia standardów konwencyjnych. Natomiast sytuacja w sprawie Al-Adsani była zgoła odmienna - chodziło bowiem o ustalenie, czy zobowiązania związane z zakazem tortur nakładają na państwo-stronę obowiązek nieuznawania immunitetu jurysdykcyjnego państwa pozwanego, gdy przedmiotem powództwa są tortury?

Wyrok ETPC w sprawie $A l-A d s a n i$ nieznacznie tylko przechylił szalę na rzecz zwolenników powściągliwości sędziowskiej, zarysowując mocną pozycję progresywnej mniejszości, której troską było głównie - choć nie wyłącznie - zapewnienie „maksymalnej skuteczności” normie ius cogens ${ }^{45}$. Można w związku z tym postawić pytanie, czy rzeczywiście funkcje i zastosowanie immunitetu państwa powinno zejść na plan dalszy w sytuacji „zderzenia” z peremptoryjnym charakterem zakazu tortur w prawie międzynarodowym? Odpowiedź na to pytanie nie jest oczywista. Charakter iuris cogentis zakazu tortur nie może oznaczać wyłączenia obowiązywania innych norm prawa międzynarodowego (w literaturze można spotkać się z koncepcją ,,przełamywania” innych norm przez normy iuris cogentis - teza ta wydaje się raczej karkołomna). Jak pisze Hazel Fox: „immunitet państwa nie kłóci się z zakazem zawartym w normie ius cogens, lecz przekierowuje

${ }^{43}$ Zob. pkt 66 wyroku ETPC w sprawie Al-Adsani.

${ }^{44}$ Wyrok z 7.7.1989 r.

${ }^{45}$ Por. zdanie odrębne do wyroku Al-Adsani sędziów Rozakisa i Caflischa (wsparte przez czterech innych sędziów). 
(divert) ewentualne naruszenie tego zakazu w stronę innej metody rozstrzygnięcia sporu [niż sąd państwa forum] ${ }^{46}$. Istotnie, teoria ,zderzenia” zakazu tortur oraz norm dotyczących immunitetu państwa nie jest przekonująca ${ }^{47}$.

Jedną z metod „przekierowania sporu” może być instytucja opieki dyplomatycznej - przy świadomości, że jest ona niedoskonała i w zasadzie zależna od woli państwa obywatelstwa. Można tu nawiązać do sygnalizowanej w doktrynie potrzeby rozwinięcia opieki dyplomatycznej w formie uprawnienia jednostki ${ }^{48}$, aczkolwiek teza ta jak dotąd nie znajduje wyraźnego potwierdzenia w praktyce państw. Ponadto można postawić pytanie, czy opieka dyplomatyczna może być uznana za efektywny środek, skoro de facto jest uzależniona od tego, jakie obywatelstwo posiada ofiara oraz czy państwo obywatelstwa gotowe jest wystąpić z roszczeniami w sferze międzypaństwowej.

Jak już wspomniano, tezy z wyroku Al-Adsani zostały co do zasady potwierdzone w wyroku Jones $i$ inni v. Zjednoczonemu Królestwu, w której tło faktyczne także dotyczyło poddania skarżącego torturom z rąk funkcjonariuszy Arabii Saudyjskiej. W odniesieniu do argumentacji prawnej skarżący w sprawie Jones twierdzili między innymi, że:

- rozwój prawa i praktyki międzynarodowej świadczy o odrzuceniu immunitetu jurysdykcyjnego państwa w przypadku tortur;

- tortury nie mogą być aktem wykonywania suwerenności objętym immunitetem;

- Komisja Prawa Międzynarodowego pozostawiła otwartą kwestię uchylenia immunitetu w przypadku zarzutu tortur;

- wyrok Al-Adsani błędnie opierał się na krajowych rozstrzygnięciach przy ustalaniu norm prawa międzynarodowego;

- niezasadne są obawy, że zmiana stanowiska ETPCz spowodowałaby masowe wnoszenie skarg przeciwko państwom obcym z uwagi na doktrynę forum non conveniens ${ }^{49}$.

Jak wiadomo, próba odwrócenia precedensu ze sprawy Al-Adsani nie powiodła się, czego można było się spodziewać w związku z brakiem przekazania jurysdykcji w sprawie Jones do Wielkiej Izby Trybunału. Rozstrzygając

${ }^{46}$ H. Fox, op. cit., s. 525.

${ }^{47}$ Por. J. Finke, op. cit., s. 869 i nast. Autor m.in. wywodzi, posługując się dworkinowskim odróżnieniem zasad od regut, iż problematykę immunitetu państwa należy postrzegać w kategoriach zasady (principle), a nie reguły/normy, co przynajmniej na płaszczyźnie konceptualnej pozwala uniknąć „sprzeczności” immunitetu państwa z normą zakazującą tortur o peremptoryjnym charakterze.

${ }^{48}$ J. Sandorski, Opieka dyplomatyczna a międzynarodowa ochrona praw człowieka, Poznań 2006, passim.

49 Zob. pkt 33-34 (,complaints”) zestawienia faktów i pytań do rządu pozwanego w tzw. komunikacji sprawy stronie rządowej z 18.9.2009 r. Dokument dostępny na stronie internetowej EKPC (Communicated cases collection). 
problem odwrócenia precedensu, Izba uznała, iż: „W sprawie Al-Adsani decydującą kwestią przy ocenie proporcjonalności środka było to, czy zasady immunitetu zastosowane przez sądy krajowe odzwierciedlały ogólnie uznane zasady prawa międzynarodowego publicznego w dziedzinie immunitetu państwa. (...) Chociaż Trybunał nie jest formalnie związany wcześniejszymi precedensami, w interesie pewności prawnej, przewidywalności oraz równości wobec prawa nie powinien bez ważnych powodów odchodzić od precedensów ustalonych w poprzednich sprawach (...). W przypadku gdy dany precedens jest stosunkowo niedawnym i kompleksowym (ang. comprehensive) wyrokiem Wielkiej Izby, tak jak w niniejszej sprawie, Izba, która nie jest gotowa podążyć za ustalonym precedensem, powinna zaproponować przekazanie sprawy do Wielkiej Izby. Żadna ze stron w niniejszej sprawie nie zwróciła się o jej przekazanie do Wielkiej Izby, a w każdym razie to do Izby należy decyzja, czy uwzględnić tego rodzaju wniosek (...). Zważywszy na precedens ustanowiony w sprawie Al-Adsani oraz szczegółowe zbadanie w tym wyroku właściwych kwestii prawnych z odniesieniem do orzecznictwa tego Trybunału oraz prawa międzynarodowego, Trybunał nie uznaje za zasadne przekazywanie niniejszej sprawy do Wielkiej Izby $(\ldots)^{50}$.

Oceniając tendencje w prawie o immunitecie państwa, jakie mogły pojawić się pomiędzy wydaniem wyroku w sprawie Al-Adsani (2001 r.) a rozstrzygnięciem sprawy Jones przed sądami brytyjskimi (2006 r.), ETPC postanowił nie przedstawiać własnej oceny, lecz oprzeć się w całości na stanowisku MTS w sprawie immunitetów jurysdykcyjnych państwa. Zdaniem ETPC wyrok MTS w sprawie niemiecko-włoskiej należy traktować jako autorytatywny w odniesieniu do treści zwyczajowego prawa międzynarodowego, a zatem w czasie jego wydawania (luty 2012 r.) nie wyksztatcit się jeszcze wyjątek ius cogens od immunitetu państwa ${ }^{51}$.

Rozstrzygnięcie sprawy Jones $i$ inni w zakresie immunitetu państwa można potraktować jako klasyczny przykład zastosowania rozumowania per rationem decidendi, z podkreśleniem wiodącego charakteru ustaleń MTS co do treści prawa międzynarodowego publicznego dotyczącego immunitetu państwa. Wyrok ten nie jest zaskoczeniem, zwłaszcza że orzecznictwo sądów krajowych już po wydaniu wyroku Al-Adsani nie upoważniało do stawiania tezy o radykalnej zmianie stanowiska, pociągającego ze sobą umocnienie ,wyjątku ius cogens". Jednak podobnie jak w przypadku prawa o immunitecie funkcjonariuszy państwa, nie można wykluczać ewolucji w tej dziedzinie wraz z okresowym weryfikowaniem precedensu Al-Adsani stosownie do rozwoju prawa międzynarodowego.

${ }^{50}$ Zob. pkt 194-195 wyroku ETPC w sprawie Jones.

51 Zob. ibidem, pkt 198. 


\section{Problem skuteczności powoływania się przez państwo pozwane na immunitet w związku z wyrządzeniem szkody na osobie wskutek działania sił zbrojnych}

W wyroku McElhinney v. Irlandii z 21.11.2001 r. Wielka Izba uznała (stosunkiem głosów 12 do 5) brak naruszenia art. 6 ust. 1 Konwencji z tytułu odmowy rozpoznania powództwa skarżącego przeciwko Zjednoczonemu Królestwu w sądach irlandzkich w związku z incydentem, do jakiego doszło na granicy Irlandii i Irlandii Północnej. Skarżący wywodził, że funkcjonariusz brytyjskiej służby granicznej użył broni już na terytorium Irlandii, powodując bezpośrednie zagrożenie życia. Powództwo skarżącego przeciwko funkcjonariuszowi oraz British Secretary of State for Northern Ireland zostało oddalone przez sądy irlandzkie, gdyż brytyjski sekretarz stanu podniósł kwestię immunitetu jurysdykcyjnego Zjednoczonego Królestwa, podkreślając także, że skarżący może przedstawić swoje roszczenia przed sądami Irlandii Północnej (argument forum non conveniens).

ETPC stwierdził, że w prawie międzynarodowym istnieje tendencja do ograniczania immunitetu państwa $\mathrm{w}$ stosunku do szkód na osobie wyrządzonych działaniem lub zaniechaniem państwa forum, lecz praktyka międzynarodowa w tej dziedzinie nie ma charakteru powszechnego, a ponadto dotyczy ona przede wszystkim szkód „pospolitych” (ETPC posłużył się odniesieniem do „szkód podlegających ubezpieczeniu", np. wypadki drogowe), a nie szkód wyrządzonych w wyniku aktów należących do sfery suwerenności państwa. Działania sił zbrojnych niewątpliwie należą do tej drugiej kategorii i dotyczą drażliwych kwestii związanych ze stosunkami dyplomatycznymi oraz bezpieczeństwem państwowym. W konkluzji Trybunał uznał, że ze względu na brak normy wyłączającej możliwość powoływania się przez państwo na immunitet w przypadku szkód wyrządzonych działaniami wojennymi, ingerencja w prawo do sądu nie była sprzeczna z obowiązującym prawem międzynarodowym ${ }^{52}$.

Omawiając problem odpowiedzialności państwa przed sądami krajowymi z tytułu deliktu wyrządzonego działaniem sił zbrojnych, warto wspomnieć na marginesie o postanowieniu polskiego Sądu Najwyższego z 29 października 2010 r. $^{53}$, oddalającym skargę kasacyjną w sprawie Winicjusza Natoniewskiego przeciwko Republice Federalnej Niemiec - Federalnemu Urzędowi Kanclerskiemu. Sprawa dotyczy pacyfikacji przez niemieckie siły zbrojne wsi Szczecyn na Lubelszczyźnie w 1944 r., w wyniku której skarżący jako 6-letnie dziecko został dotkliwie poparzony. Orzekające w sprawie sądy stwierdziły brak jurysdykcji krajowej. SN oddalił skargę kasacyjną, stwierdzając m.in., iż „(...) obecnie

52 Por. pkt 38 wyroku w sprawie McElhinney.

${ }^{53}$ Sygn. akt IV CSK 465/09, http://www.sn.pl 
nie istnieje prawnomiędzynarodowy obowiązek przyznania obcemu państwu immunitetu $\mathrm{w}$ sprawach o roszczenia z czynów niedozwolonych, jeżeli działanie sprawcze miało miejsce w państwie sądu i sprawca w chwili tego działania znajdował się na obszarze państwa sądu" 54 .

Jednak po gruntownej analizie norm prawa międzynarodowego dotyczących immunitetu państwa, a także poglądów doktryny i praktyki państw, SN uznał, że „brak dostatecznych podstaw do stwierdzenia wyjątku wyłączającego spod immunitetu państwa sprawy o roszczenia z objętych działaniami zbrojnymi czynów niedozwolonych popełnionych na terytorium państwa sądu orzekającego, które były wynikiem naruszenia praw człowieka" ${ }^{55}$.

Za prawdopodobne należy uznać wniesienie skargi przez W. Natoniewskiego do ETPC w związku z zarzutami na tle art. 6 ust. 1 Konwencji, aczkolwiek wyrok MTS w sprawie niemiecko-włoskiej nie napawa optymizmem co do szans jej powodzenia. Sprawa W. Natoniewskiego ma wyraźne konotacje ze sprawami toczącymi się przed włoskimi i greckimi sądami, w których podnoszono roszczenia przeciwko Republice Federalnej Niemiec z tytułu działań wojsk niemieckich w trakcie II wojny światowej. Można uznać, że wniesienie skargi przez W. Natoniewskiego byłoby dla ETPC dobrą okazją dla wyrażenia opinii co do aktualnych tendencji ograniczających działanie immunitetu jurysdykcyjnego państwa w związku z wyrządzeniem szkody na osobie wskutek działania sił zbrojnych.

Skądinąd uzasadnienie postanowienia polskiego Sądu Najwyższego z 29 października 2010 r. nie daje podstaw do jego zasadniczej kontestacji z perspektywy prawa międzynarodowego publicznego, $\mathrm{w}$ tym interpretacji i zastosowania reguł wyrażonych w dotychczasowym orzecznictwie strasburskim (licznie przywoływanych przez SN). Skarżący miał jednak prawo do przedstawienia przed ETPC zarzutu ograniczenia prawa dostępu do sądu niezgodnego z art. 6 ust. 1 Konwencji, wskazując - podobnie jak skarżący w sprawie Jones $i$ inni - potrzebę ponownego przewartościowania tez zawartych m.in. w wyroku Al-Adsani, czy też uzasadniając swoje racje interpretacją EKPC jako living instrument.

\section{Podsumowanie}

Orzecznictwo ETPC dotyczące immunitetu jurysdykcyjnego państwa charakteryzuje się powściągliwością sędziowską i uwzględnia funkcje tego immunitetu w prawie międzynarodowym. Dotyczy to w szczególności trzech precedensowych rozstrzygnięć ETPC dotyczących immunitetu z 2001 r. Obecnie należy

${ }^{54}$ Por. s. 15 uzasadnienia postanowienia SN.

${ }_{55}$ Por. ibidem, s. 28. 
odnotować jednak dążenie do ograniczania mocy immunitetu w sprawach pracowników misji dyplomatycznych (orzeczenie w sprawie Cudak v. Litwie) oraz nieudaną próbę podważenia rationes decidendi wyroku w sprawie Al-Adsani v. Zjednoczonemu Królestwu w związku ze sprawą Jones $i$ inni rozstrzygniętą przez ETPC w $2014 \mathrm{r}$.

Zauważalne są wśród części doktryny, a także organizacji pozarządowych i niektórych sędziów ETPC, tendencje do relatywizacji znaczenia immunitetu państwa w szerszym kontekście, tzn. postulowanie „odrębności” norm Konwencji od reżimu powszechnego prawa międzynarodowego. Jest to tendencja niebezpieczna i prowadzić może do dalszej fragmentaryzacji porząaku prawnomiędzynarodowego. Naturalnie nie można pomijać konsekwencji peremptoryjnego charakteru niektórych (nielicznych) norm chroniących prawa człowieka (zakaz tortur, zakaz niewolnictwa i poddaństwa), jednak nie należy zapominać o konieczności interpretacji tych norm w symbiozie z innymi uznanymi normami prawa międzynarodowego.

Dynamika zmian w prawie o immunitecie państwa powinna być postrzegana jako funkcja ewolucji suwerenności. Immunitet można i należy uznać za jedną z konsekwencji suwerenności państwa - nie bez powodu w doktrynie używa się pojęcia principle of sovereign immunity. Rozwój praktyki państw odnośnie do immunitetu pozostaje zatem w ścisłym związku z przeobrażeniami koncepcji suwerenności w prawie i stosunkach międzynarodowych.

Niezmiernie istotne jest harmonizowanie stanowisk dotyczących immunitetu państwa w rozstrzygnięciach sądów międzynarodowych. Dotychczas ETPC wykazywał gotowość uwzględniania wyroków MTS w sprawach bezpośrednio związanych z normami powszechnego prawa międzynarodowego. Należy odnotować, że - jak dotąd - orzeczenia ETPC i MTS dotyczące immunitetu są ze sobą spójne. Zmiany w prawie o immunitecie państwa oraz jego funkcjonariuszy - jeśli nastąpią - powinny być ugruntowane najpierw w orzecznictwie sądów krajowych oraz analizach doktrynalnych, takich jak raporty i projekty Komisji Prawa Międzynarodowego ONZ. Kreatywność sądów międzynarodowych nie może zastępować działalności prawotwórczej państw. Dotyczy to także prawa o immunitecie państwa. 